DOI: https://doi.org/10.31933/jemsi.v2i4

Received: 25 Februari 2021, Revised: 10 Maret 2021, Publish: 12 Maret 2021

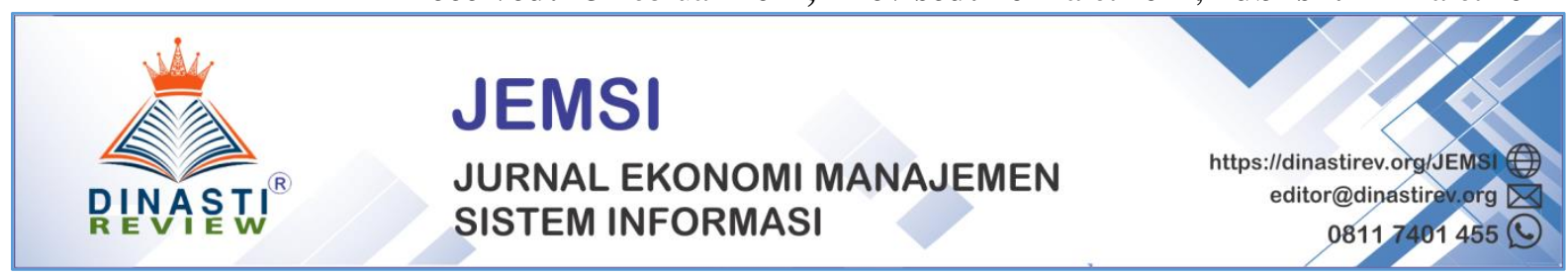

\title{
PENGARUH DAYA TARIK IKLAN TELEVISI, LITERASI EKONOMI, DAN KONTROL DIRI TERHADAP PEMBELIAN IMPULSIF (STUDI KASUS GURU SMA NEGERI KABUPATEN MUSI BANYUASIN)
}

\author{
Suratno Suratno ${ }^{1}$, Denny Denmar ${ }^{2}$, Hepy Hepy $^{3}$ \\ 1) Dosen Program Studi Magister Pendidikan Universitas Jambi, Jambi, Indonesia, Email: \\ suratnounja@gmail.com \\ 2) Dosen Program Studi Magister Pendidikan Universitas Jambi, Jambi, Indonesia, Email: \\ dennydenmar101264@gmail.com \\ 3) Alumni Program Studi Magister Pendidikan Universitas Jambi, Jambi, Indonesia, Email: \\ hepy06808@gmail.com
}

\begin{abstract}
Abstrak: Penjualan ritel yang menurun pada tahun 2017 di Indonesia membuat beberapa ritel ternama seperti 7-Eleven, Clarks Indonesia, Banana Republic, GAP, Dorothy Perkins, dan New Look menutup gerai toko mereka di Indonesia. Selain penjualan ritel yang menurun, pertumbuhan toko ritel modern di Indonesia juga mengalami penurunan dari tahun 2016 yakni dari yang awalnya di angka 9\% menjadi 7,5\% pada tahun 2017. Faktor yang membuat beberapa toko ritel menutup gerai mereka adalah karena adanya e-commerce yang menjadi pesaing kuat dari ritel konvensional pada saat sekarang ini. Daya beli masyarakat yang masih rendah juga menjadi faktor lainnya yang membuat penjualan ritel di tahun 2017 menurun. Berdasarkan hasil penelitian, didapatkan hasil bahwa terdapat pengaruh yang signifikan antara daya tarik iklan televisi terhadap pembelian impulsif dengan arah pengaruh positif. Ini mengandung arti bahwa daya tarik iklan televisi yang semakin baik akan meningkatkan pembelian impulsif guru. Sedangkan pada variabel literasi ekonomi erdapat pengaruh yang signifikan antara literasi ekonomi terhadap pembelian impulsif dengan arah pengaruh negatif. Ini mengandung arti bahwa rendahnya literasi ekonomi maka akan meningkatkan pembelian impulsif guru serta pada variabel kontrol diri terdapat pengaruh yang signifikan antara kontrol diri terhadap pembelian impulsif dengan arah pengaruh negatif. Ini mengandung arti bahwa rendahnya kontrol diri maka akan meningkatkan pembelian impulsif guru. Diharapkan pada pihak Produsen harus banyak memiliki inovasi-inovasi baru dan selalu peka mengikuti perkembangan trend yang muncul di mansyarakat khususnya guru untuk memancing impulsivitas konsumen terhadap produknya. Iklaniklan dibuat semenarik mungkin dan bersifat sugestibel serta mudah dilihat sehingga lebih dapat menimbulkan ketertarikan yang mendorong guru melakukan impulsive buying pada produk tersebut. Untuk memasarkan produk juga bisa dilakukan melalui internet yaitu marketplace, online shop di sosial media seperti facebook, instagram dan masih banyak lagi.
\end{abstract}

Kata Kunci: Pembelian Impulsif, Daya Tarik Iklan Televisi, Literasi Ekonomi, Kontrol Diri.

\section{PENDAHULUAN}

Pengaruh globalisasi sangat terlihat di kota-kota besar termasuk Palembang. Pengaruh tersebut terlihat dari semakin pesatnya perkembangan pembangunan khususnya di bidang ekonomi. Terlebih lagi di kota Palembang terdapat berbagai pusat perbelanjaan seperti 
minimarket, supermarket, mall, butik, distro, serta pusat perbelanjaan lainnya seperti pertokoan di sepanjang Jembatan Ampera, Plaju, Kenten, Palembang Ulu maupun Ilir. Arus globalisasi juga menyebabkan semakin banyaknya produk impor masuk ke pasar domestik, sehingga mempermudah masyarakat untuk menjangkau produk tersebut tanpa harus pergi ke luar negeri. Beberapa shopping mall terkenal dan sering dikunjungi oleh masyarakat Palembang yang banyak menawarkan berbagai produk impor antara lain adalah Palembang Indah Mall, Palembang Square Mall, Lippo Plaza Jakabaring, Palembang Icon Mall, OPI Mall, Palembang Trade Center, Transmart Palembang City Center, International Plaza, Lotte Mart Whosale Palembang, Ramayana Departement Store dan Giant Hypermarket.

Banyaknya pembangunan mall di kota-kota besar menunjukkan tingginya budaya konsumtif di kalangan masyarakat. Para investor cenderung memilih membangun mall di daerah perkotaan, dengan anggapan bahwa masyarakat perkotaan berada di kelas ekonomi menengah ke atas. Dalam perkembangannya mall bertransformasi tidak hanya sekedar tempat berbelanja namun juga sebagai tempat hiburan. Langkah tersebut biasanya dilakukan oleh pihak mall untuk menarik perhatian orang mengunjungi mall dan tanpa disadari perkembangan ini justru menyebabkan pergeseran perilaku konsumsi masyarakat menjadi lebih konsumtif.

Berdasarkan penelitian yang dilakukan oleh Nielsen (2017) melalui wawancara tatap muka dengan 1804 responden di Bandung, Jakarta, Makassar, Medan dan Surabaya dengan belanja rumah tangga lebih dari Rp 1,5 juta per bulan. Dua aspek perilaku yaitu "tidak pernah membuat rencana pembelian" naik dari angka 12\% (2015) belanjaan" yang meningkat dari 16\% (2015) menjadi 41\% (2016). Hal ini menunjukan gambaran bahwa perilaku impulse buying sangat berkembang di masyarakat Indonesia.

Menurut Paramita, Arifin dan Sunarti (2014:5) Pembelian impulsif adalah keinginan mendadak pembelian sebuah produk tanpa perencanaan maupun keinginan pembelian sebelumnya yang tanpa melalui banyak pertimbangan dan cenderung menggunakan emosi dalam proses pengambilan keputusan pembelian. Pembelian impulsif merupakan fenomena psikoekonomik yang banyak melanda kehidupan masyarakat. Pada proses membeli impulsif, calon pembeli langsung mengarah kepada suatu produk tertentu dan kemudian melakukan pembelian secara cepat. Perilaku pembelian impulsif timbul secara tidak sadar pada saat individu melakukan kegiatan yang berkaitan dengan uang dan gaya hidup. Sebagai contoh, ketika seseorang dengan teman sebayanya berjalan-jalan di pusat perbelanjaan atau mall yang tujuannya hanya sekedar jalan-jalan atau mengisi waktu luang kemudian melihat produk dengan model terbaru atau melihat adanya potongan harga (discount) pada produk tertentu, akhirnya memutuskan membeli meskipun ketika berangkat tidak ada rencana untuk membeli.

Penelitian bermaksud untuk mengkaji perilaku pembelian impulsive guru pada SMA Negeri Kabupaten Musi Banyuasin melalui Daya Tarik Iklan Televisi, Literasi Ekonomi, dan Kontrol Diri. Berdasarkan uraian latar belakang yang telah disebutkan, penulis tertarik untuk melakukan penelitian dengan judul "Pengaruh Daya Tarik Iklan Televisi, Literasi Ekonomi, dan Kontrol Diri terhadap Pembelian Impulsif (Studi Kasus Guru SMA Negeri Kabupaten Musi Banyuasin)".

Penelitian ini dilakukan dengan tujuan untuk menganalisis: 1) Mengetahui besarnya kontribusi Daya Tarik Iklan Televisi terhadap Pembelian Impulsif (Studi Kasus Guru SMA Negeri Kabupaten Musi Banyuasin); 2) Mengetahui besarnya kontribusi Literasi Ekonomi terhadap Pembelian Impulsif (Studi Kasus Guru SMA Negeri Kabupaten Musi Banyuasin); 3) Mengetahui besarnya kontribusi Kontrol Diri terhadap Pembelian Impulsif (Studi Kasus 
Guru SMA Negeri Kabupaten Musi Banyuasin); dan 4) Mengetahui besarnya kontribusi Daya Tarik Iklan Televisi, Literasi Ekonomi, dan Kontrol Diri secara bersama-sama terhadap Pembelian Impulsif (Studi Kasus Guru SMA Negeri Kabupaten Musi Banyuasin).

\section{KAJIAN PUSTAKA \\ Pembelian Impulsif}

Pembelian impulsif adalah pembelian yang dilakukan konsumen ketika melihat produk atau merek tertentu, kemudian tertarik untuk membeli karena rangsangan ataupun dorongan yang menarik dari toko tersebut (Utami, 2010:51). Menurut Stern dalam Bong (2011) pembelian impulsif adalah suatu pembelian yang tanpa perencanaan sebelumnya. Kemudian Lisda (2010:56) menyatakan bahwa pembelian impulsif (impulsive buying) adalah proses pembelian suatu barang, dimana pembeli tidak mempunyai niat untuk membeli sebelumnya, dapat dikatakan pembelian tanpa rencana atau pembelian seketika. Menurut Abbas (2015) pembelian impulsif merupakan perilaku yang ditunjukkan oleh konsumen dihadapkan dengan yang instan, berorientasi afektif dan cepat. Menurutnya pembelian impulsif dipengaruhi pengalaman individu dan latar belakang masa lalu.

Menurut Verplanken dan Herabadi dalam Marhayati (2012), menyatakan bahwa terdapat dua aspek penting dalam pembelian impulsif yaitu: 1) Aspek kognitif yang meliputi kegiatan pembelian yang dilakukan tanpa pertimbangan harga suatu produk, kegiatan pembelian tanpa mempertimbangkan kegunaan suatu produk, dan individu tidak melakukan perbandingan produk; dan 2) Aspek afektif yang meliputi adanya dorongan perasaan untuk segera melakukan pembelian, adanya perasaan kecewa yang muncul setelah melakukan pembelian dan adanya proses pembelian yang dilakukan tanpa perencanaan.

Adapun karakteristik pembelian impulsif seseorang menurut Rook \& Fisher dalam Kharis (2011) dapat diukur melalui: 1) Spontanitas yaitu pembelian yang tidak diharapkan dan memotivasi konsumen untuk membeli saat itu juga serta sering menjadi respon terhadap stimulasi visual langsung ditempat penjualan; 2) Kekuatan, kompulsi dan intensitas yang berarti adanya motivasi untuk mengesampingkan semua hal dan bertindak dengan seketika; 3) Kegairahan dan stimulasi yang berarti adanya desakan secara mandadak untuk membeli barang dan disertai dengan emosi yang dicirikan sebagai menggairahkan, menggetarkan atau liar; dan 4) Ketidakpedulian akan akibat artinya desakan untuk membeli barang menjadi sulit untuk ditolak sehingga akibat negatif sering diabaikan.

Berdasarkan beberapa teori diatas, maka dapat disintesiskan bahwa pembelian impulsif adalah pembelian yang tidak rasional dan terjadi secara spontan karena munculnya dorongan yang kuat untuk membeli dengan segera pada saat itu juga dan adanya perasaaan positif yang kuat mengenai suatu benda, sehingga pembelian berdasar impuls tersebut cenderung terjadi dengan adanya perhatian dan mengabaikan konsekuensi negatif dengan indikatorindikatornya meliputi : (1) Pembelian spontan, merupakan keadaan dimana pelanggan seringkali membeli sesuatu tanpa direncakan terlebih dahulu, (2) Pembelian tanpa berpikir akibat, merupakan keadaan dimana pelanggan sering melakukan pembelian tanpa memikirkan terlebih dahulu mengenai akibat dari pembelian yang dilakukan, (3) Pembelian terburu-buru, merupakan keadaan dimana pelanggan seringkali merasa bahwa terlalu terburuburu dalam membeli sesuatu, (4) Pembelian dipengaruhi keadaan emosional, adalah penilaian pelanggan dimana pelanggan melakukan kegiatan berbelanja dipengaruhi oleh keadaan emosional yang dirasakan. 


\section{Daya Tarik Iklan}

Iklan adalah sebagai pesan-pesan yang unsur seni, teks/tulisan, judul, foto-foto, tageline, unsur-unsur lainnya yang telah dikembangkan untuk kesesuaian mereka (Keegan dan Green dalam Rahman, 2012:21). Menurut Kustandi dalam Rahman, (2012:21) iklan adalah suatu proses komunikasi masa yang melibatkan sponsor tertentu, yang membayar jasa sebuah media massa atas penyiaran iklannya.

Iklan memiliki sejumlah fungsi sesuai dengan dimaksudkan oleh perancangan atau pengiklannya. Dendy (2010:3) juga mengungkapkan ada lima fungsi periklanan sebagai berikut: 1) Memberikan informasi atas produk; 2) Membujuk atau mempengaruhi konsume untuk mengkonsumsi produk; 3) Memuaskan keinginan (orang ingin mengetahui kandungan gizi, vitamin atau suatu produk); 4) Merupakan alat konsumsi; dan 5) Menjaring khalayak.

Iklan pada dasarnya bertujuan untuk menjalankan tugas mengkomunikasikan informasi untuk mencapai pelanggan khusus, bahwa perusahaan mencoba mencapai audiens dalam jangka waktu tertentu. Perusahaan pengiklan selalu memilih salah satu atau lebih dari empat tujuan ini, yakni mencoba, melanjutkan, memperkenalkan merek baru atau membayangkan suatu produk di masa lalu. Para praktisi iklan selalu merumuskan tujuan iklan dari produsen suatu produk atas tiga tujuan sebagai berikut (Liliweri, 2011:539 - 540): 1) Mengirimkan Informasi; 2) Mempersuasi Audiens; 3) dan Mengingatkan audiens.

Berdasarkan uraian diatas dapat dirumuskan bahwa yang dimaksud dengan daya tarik iklan dalam penelitian ini adalah "segala bentuk penyajian dan promosi ide, barang atau jasa secara non-personal oleh suatu sponsor tertentu yang memerlukan pembayaran. Indikator daya tarik iklan dalam penelitian ini harus memenuhi kriteria yaitu : (1) Attention, (2) Interest, (3) Desire, (4) Conviction, dan (5) Action.

\section{Literasi Ekonomi}

Literasi ekonomi merupakan alat yang berguna untuk mengubah perilaku dari tidak cerdas menjadi cerdas. Seperti bagaimana memanfaatkan pendapatan untuk menabung, berinvestasi, proteksi dan memenuhi kebutuhan hidup. Literasi ekonomi juga berguna untuk membuka persepsi yang terbelenggu akibat kurangnya pengetahuan tentang biaya/manfaat (cost/benefit) (Peter Sina, 2012:135). Menurut Jappelli dalam Nuraeni (2015:18) literasi ekonomi merupakan alat untuk mencapai tujuan, hanya saja pada kenyataannya tidak semua orang memiliki literasi ekonomi yang tinggi sehingga mengkerucutkan peluang mencapai kesejahteraan. Salah satu indikatornya adalah menjadi orang yang cerdas dalam mengelola sumber daya ekonominya guna mencapai kesejahteraan.

Beberapa survei dilakukan untuk melihat tingkat melek (literasi) ekonomi, khususnya di Amerika Serikat. Salah satunya adalah Survei yang dilakukan pada bulan September dan Oktober 1998 oleh The Minnesota Center for Survey Research at the University of Minnesota. Survei dilakukan dengan mengajukan 13 pertanyaan untuk menguji pengetahuan yang terkait dengan konsep-konsep ekonomi atau literasi ekonomi (Budiwati, 2014:17). Hasil yang diperoleh dari tes ini adalah bahwa sebagian besar responden menunjukkan pemahaman yang baik tentang prinsip-prinsip ekonomi (khususnya isu ekonomi mikro, seperti operasi pasar dan sumber-sumber pendapatan pribadi) dan memiliki dampak langsung terbesar pada kehidupan sehari-hari mereka, khususnya terkait isu-isu ekonomi mikro. Akan tetapi responden kurang memahami isu-isu ekonomi makro, seperti peran uang dan penyebab dan 
dampak inflasi yang ditunjukkan oleh data sekitar 54\% responden tidak memahami hubungan antara uang dan defisit anggaran, serta 35\% responden tidak memahami tentang pengambilan keputusan yang berkaitan dengan sumber daya yang terbatas (Budiwati, 2014:18).

Literasi ekonomi adalah gambaran kemampuan individu dalam memahami konsep dasar ekonomi yang dapat digunakan untuk memuat keputusan ekonomi yang tepat untuk meningkatkan kesejahteraan hidup dengan indikator-indikatornya meliputi: 1) Mampu menjelaskan pengaruh lingkungan sosial; 2) Mampu menjelaskan penggunaan sumber daya yang terbatas; dan 3) Mampu menganalisis manfaat dan biaya dari transaksi ekonomi.

\section{Kontrol Diri}

Kontrol diri merupakan suatu kecakapan individu dalam kepekaan membaca situasi diri dan lingkungannya. Selain itu, juga kemampuan untuk mengontrol dan mengelola faktorfaktor perilaku sesuai dengan situasi dan kondisi untuk menampilkan diri dalam melakukan sosialisasi kemampuan untuk mengendalikan perilaku, kecenderungan menarik perhatian, keinginan mengubah perilaku agar sesuai untuk orang lain, menyenangkan orang lain, selalu konform dengan orang lain, dan menutupi perasaannya (Ghufron, 2014:21).

Menurut Syamsul (2010:107) kontrol diri merupakan individu untuk mengendalikan dorongan-dorongan, baik dari dalam maupun dari luar diri individu. Individu yang memiliki kemampuan kontrol diri akan membuat keputusan dan mengambil langkah tindakan yang efektif sehingga menghasilkan sesuatu yang diinginkan dan menghindari akibat yang tidak diinginkan. Sedangkan menurut Menurut Goldfried dan Merbaum dalam Ghufron (2014:22) mendefinisikan kontrol diri sebagai suatu kemampuan untuk menyusun, membimbing, mengatur dan mengarahkan bentuk perilaku yang dapat membawa individu ke arah konsekuensi positif. Sejalan dengan pendapat Tangney yang dikutip dalam Hoyri (2014:52) bahwa kontrol diri merupakan "kemampuan individu untuk menentukan perilakunya berdasarkan standar tertentu seperti moral, nilai dan aturan di masyarakat agar mengarah pada perilaku positif".

Menurut Block dan Block dalam Ghufron (2014:31) mengemukakan tiga jenis kontrol, yaitu: 1) Over control, yaitu kontrol yang berlebihan sehingga menyebabkan seseorang banyak mengontrol dan menahan diri untuk bereaksi terhadap suatu stimulus; 2) Appropriate control, yaitu kontrol yang memungkinkan individu mengendalikan implusnya dengan tepat; dan 3) Under control, yaitu kecenderungan untuk melepaskan impulsivitas dengan bebas tanpa perhitungan yang matang.

Berdasarkan uraian diatas dapat dirumuskan bahwa yang dimaksud dengan kontrol diri dalam penelitian ini adalah "kemampuan individu untuk menentukan perilakunya berdasarkan standar tertentu seperti moral, nilai dan aturan di masyarakat agar mengarah pada perilaku positif". Indikator dalam penelitian ini yaitu: 1) Kemampuan mengontrol perilaku; 2) Kemampuan menafsirkan keadaan atau peristiwa; dan 3) Kemampuan mengambil keputusan.

\section{Kerangka Berpikir}

Berdasarkan dari uraian tersebut maka dapat diketahui bahwa variabel terikat pembelian impulsif berhubungan dengan berbagai variabel bebas, diantaranya daya tarik iklan televisi, literasi ekonomi dan kontrol diri. Dengan demikian, maka kerangka penelitian dapat digambarkan sebagai berikut. 


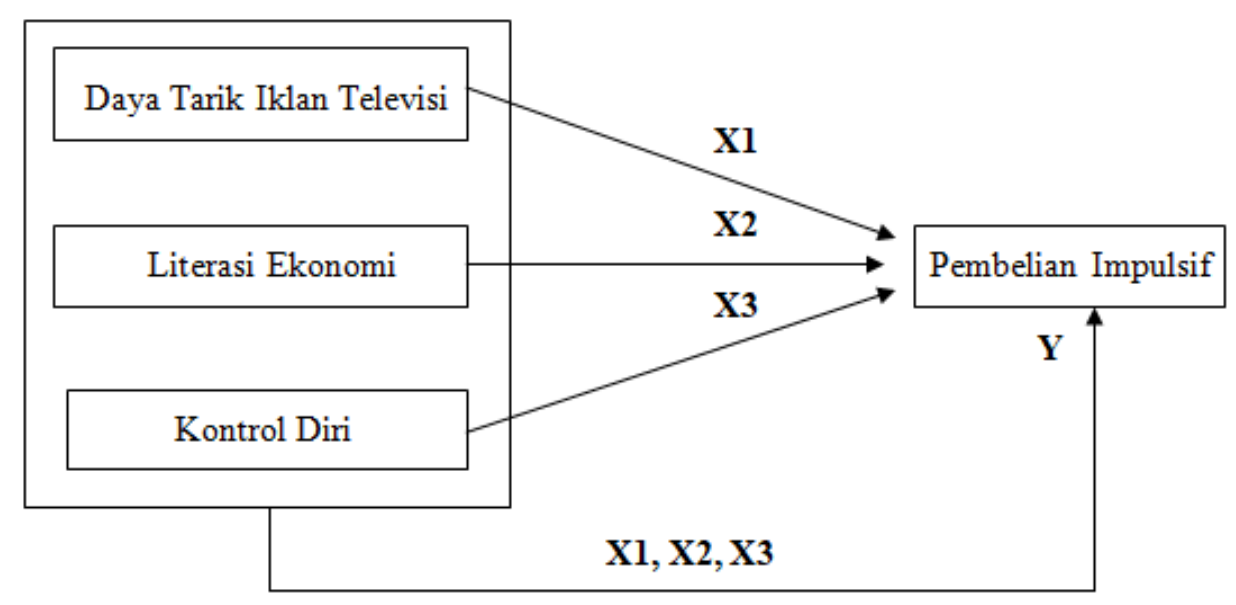

Gambar 1. Kerangka Berpikir

Keterangan :

$\mathrm{X}_{1}-\mathrm{Y} \quad$ : Bagaimana pengaruh daya tarik iklan televisi terhadap pembelian impulsif

$\mathrm{X}_{2}-\mathrm{Y} \quad$ : Bagaimana pengaruh literasi ekonomi terhadap pembelian impulsif

$\mathrm{X}_{3}-\mathrm{Y} \quad$ : Bagaimana pengaruh kontrol diri terhadap pembelian impulsif

$\mathrm{X}_{1}, \mathrm{X}_{2}, \mathrm{X}_{3}-\mathrm{Y}$ : Bagaimana pengaruh secara simultan antara daya tarik iklan televisi, literasi ekonomi dan kontrol diri terhadap pembelian impulsif

Dari gambar diatas dapat diartikan hubungan antar variabel yaitu :

H1 : Terdapat pengaruh daya tarik iklan televisi terhadap pembelian implulsif.

$\mathrm{H} 2$ : Terdapat pengaruh literasi ekonomi terhadap pembelian implulsif.

H3 : Terdapat pengaruh kontrol diri terhadap pembelian implulsif.

H4 : Terdapat pengaruh secara simultan antara daya tarik iklan televisi, literasi ekonomi dan kontrol diri terhadap pembelian impulsive.

\section{METODE PENELITIAN}

Penelitian merupakan suatu proses mencari sesuatu secara sistematik dalam waktu yang lama dengan menggunakan metode ilmiah serta aturan-aturan yang berlaku untuk dapat menghasilkan suatu penelitian yang baik. Menurut Sugiyono (2017:2) yang dimaksud dengan metode penelitian pada dasarnya merupakan cara ilmiah untuk mendapatkan data dengan tujuan dan kegunaan tertentu. Dalam penelitian ini, penulis menggunakan metode penelitian kuantitatif Menurut Sugiyono (2017:8) penelitian kuantitatif adalah metode penelitian yang berlandaskan pada filsafat positivisme, digunakan untuk meneliti pada populasi atau sampel tertentu, pengumpulan data menggunakan instrument penelitian, analisis data bersifat kuantitatif atau statistik, dengan tujuan untuk menguji hipotesis yang telah ditetapkan.

Populasi dalam penelitian ini adalah seluruh guru SMA se-Kabupaten Musi Banyuasin. Pertimbangan untuk menentukan populasi se-Kabupaten Musi Banyuasin terutama didasarkan pada pokok permasalahan penelitian yang diduga lebih dapat digeneralisasikan bagi guru yang berada di Kabupaten Musi Banyuasin. Teknik sampling pada penelitian ini menggunakan teknik sampling jenuh. Sampling jenuh adalah teknik pengambilan sampel bila 
semua anggota populasi digunakan sebagia sampel, ini syaratnya populasi tidak banyak atau peneliti ingin membuat generalisasi dengan kesalahan sangat kecil. Dalam hal ini yang dijadikan sampel adalah populasi yaitu guru SMA Negeri Kabupaten Musi Banyuasin.

Sebelum analisis, dilakukan uji instrumen kuesioner dengan uji validitas dan reliabilitas; uji prasyarat melalui uji normalitas, homogenitas, dan linearitas; derta uji asumsi regresi melalui uji multikolinearitas, uji heterokedastisitas, dan uji autokorelasi.

\section{HASIL DAN PEMBAHASAN \\ Deskripsi Variabel Penelitian}

Berdasarkan hasil analisis, maka dapat di deskripsikan sebagai berikut:

1. Deskripsi Pembelian Impulsif

Secara deskriptif diperoleh skor tertinggi 89 dan yang terendah guru mendapatkan nilai 64. Sedangkan standar deviasi adalah 6,354 ini berarti bahwa titik data individu jauh dari nilai rata-rata. Nilai rata-rata skor pada variabel pembelian impulsif adalah 75,67. skor 75,67 ini bila dibagikan 25 soal angket maka akan didapatkan 3,02, maka rata-rata skor jawaban per item pada variabel ini bernilai 3,02 bila dilihat pada skala likert akan termasuk kedalam kategori baik yaitu pada rentang 2,51-3,50. dengan ini maka disimpulkan bahwa variabel pembelian impulsif guru SMA Negeri Kabupaten Musi Banyuasin termasuk kategori baik.

2. Deskripsi Penggunaan Daya Tarik Iklan

Secara deskriptif daya tarik iklan televisi dapat disimpulkan bahwa nilai tertinggi dengan nilai 90 sedangkan terendah dengan nilai 69. Jangkauan dari nilai tertinggi ke nilai terendah atau yang disebut range sebesar 21. Sedangkan standar deviasi adalah 5,670 ini berarti bahwa titik data individu tidak jauh dari nilai rata-rata. Dari 42 responden maka didapatkan mean atau rata-rata daya tarik iklan televisi secara keseluruhan adalah 79,00. bila 79,00 dibagikan 25 pernyataan maka akan didapatkan hasil 3,16 atau termasuk kategori baik yaitu pada rentang 2,51-3,50. Maka dengan ini dinyatakan bahwa variabel daya tarik iklan televisi termasuk kategori baik.

3. Deskripsi Literasi Ekonomi

Secara deskriptif literasi ekonomi dapat disimpulkan bahwa nilai tertinggi dengan nilai 52 sedangkan terendah dengan nilai 25. Jangkauan dari nilai tertinggi ke nilai terendah atau yang disebut range sebesar 27. Sedangkan standar deviasi adalah 7,121 ini berarti bahwa titik data individu tidak jauh dari nilai rata-rata. Dari 42 responden maka didapatkan mean atau rata-rata literasi ekonomi secara keseluruhan adalah 36,21. Bila 36,21 dibagikan 25 pernyataan maka akan didapatkan hasil 1,50 atau termasuk kategori kurang baik baik yaitu pada rentang 1,50-2,50. Maka dengan ini dinyatakan bahwa variabel literasi ekonomi termasuk kategori kurang baik.

\section{Deskripsi Kontrol Diri}

Secara deskriptif kontrol diri dapat disimpulkan bahwa nilai tertinggi dengan nilai 55 sedangkan terendah dengan nilai 25. Jangkauan dari nilai tertinggi ke nilai terendah atau yang disebut range sebesar 30. Sedangkan standar deviasi adalah 8,328 ini berarti bahwa titik data individu tidak jauh dari nilai rata-rata. Dari 42 responden maka didapatkan mean atau rata-rata kontrol diri secara keseluruhan adalah 36,64. Bila 36,64 dibagikan 25 pernyataan maka akan didapatkan hasil 1,50 atau termasuk kategori 
kurang baik yaitu pada rentang 1,50-2,50. Maka dengan ini dinyatakan bahwa variabel kontrol diri termasuk kategori kurang baik.

\section{Uji Prasyarat}

Dari hasil uji yang dilakukan dengan menggunkan bantuan SPSS 22.0 for windows di simpulkan bahwa Variabel pembelian impulsif dinyatakan normal karena nilai Sig. 0,620 > 0,05, Variabel daya tarik iklan televisi dinyatakan normal karena nilai Sig. 0,051>0,05, Variabel literasi ekonomi dinyatakan normal karena nilai Sig. 0,092 > 0,05, dan Variabel kontrol diri dinyatakan normal karena nilai Sig. 0,062>0,05.

Kemudian dari hasil uji homogenitas menggunakan SPSS 22.0 diperoleh bahwa 1) Variabel daya tarik iklan televisi dan pembelian impulsif dinyatakan Homogen karena nilai Sig. 0,152 > 0,05; Variabel literasi ekonomi dan pembelian impulsif dinyatakan Homogen karena nilai Sig. 0,214 > 0,05; dan Variabel kontrol diri dan pembelian impulsif dinyatakan Homogen karena nilai Sig. 0,225 > 0,05. Maka dengan ini dinyatakan bahwa seluruh variabel didalam penelitian ini bersifat homogen.

\section{Hasil Uji Klasik}

Dari hasil uji heterokedastisitas diperoleh hasil Variabel daya tarik iklan televisi dengan pembelian impulsif dinyatakan tidak terjadi heteroskedastisitas karena nilai Sig. 0,207 > 0,05; Variabel kontrol diri dengan pembelian impulsif dinyatakan tidak terjadi heteroskedastisitas karena nilai Sig. 0,756 > 0,05; dan Variabel literasi ekonomi dengan pembelian impulsif dinyatakan tidak terjadi heteroskedastisitas karena nilai Sig. 0,311 >0,05. Dari hasil tersebut maka dapat disimpulkan semua variabel dalam penelitian ini tidak mengalami gejala masalah heteroskedastisitas.

Kemudian dari hasil uji multikolinieritas menunjukan bahwa semua variable penelitian memiliki nilai VIF (variance inflation factor) di atas lebih kecil dari 10, dimana Variabel daya tarik iklan televisi dan pembelian impulsif dinyatakan tidak terjadi multikolinieritas karena nilai VIP $1,052<10$; Variabel literasi ekonomi dan pembelian impulsif dinyatakan tidak terjadi multikolinieritas karena nilai VIP 7,238< 10 ; dan Variabel kontrol diri dan pembelian impulsif dinyatakan tidak terjadi multikolinieritas karena nilai VIP 7,196< 10 .

Selanjutnya dari hasil uji autokorelasi yang dilakukan diperoleh nilai Durbin Watson 2,550. Sedangkan nilai tabel Sig. 5\% untuk jumlah sampel 42 orang dengan jumlah variabel $\mathrm{X}$ sebanyak $3(\mathrm{~K}=3)=1,3573$. Jika dibandingkan nilai DW dengan nilai tabel maka diperoleh 2,550 > 1,3573 maka disimpulkan tidak terdapat gejala autokorelasi antar variabel.

Berdasarkan dari hasil uji prasyarat dan hasil uji asumsi regresi tersebut maka telah terpenuhinya Persyaratan untuk dilakukannya pengujian selanjutnya.

\section{Hasil Persamaan Regresi Linear Berganda}

Berdasarkan estimasi regresi berganda dengan program SPSS 17.0 diperoleh hasil seperti Tabel 1 berikut.

Tabel 1. Coefficients Regression

\begin{tabular}{|c|c|c|c|c|}
\hline Model & $\begin{array}{c}\text { Unstandardized } \\
\text { Coefficients }\end{array}$ & $\begin{array}{l}\text { Standardized } \\
\text { Coefficients }\end{array}$ & $\mathrm{t}$ & Sig. \\
\hline
\end{tabular}




\begin{tabular}{lrrrrr}
\hline \multicolumn{1}{c}{} & \multicolumn{1}{c}{ B } & \multicolumn{1}{c}{ Std. Error } & \multicolumn{1}{l}{ Beta } & & \\
\hline 1 (Constant) & 60,401 & 15,384 & & 3,926 &, 000 \\
D_T_I_Televisi &, 291 &, 171 &, 259 & 1,703 &, 097 \\
K_Diri &,- 141 &, 304 &,- 184 &,- 463 &, 646 \\
L_Ekonomi &,- 070 &, 356 &,- 079 &,- 197 &, 845 \\
\hline
\end{tabular}

Dari tabel di atas dapat disusun persamaan regresinya sebagai berikut.

$$
\begin{aligned}
& Y=a+b_{1} X_{1}+b_{2} X_{2}+b_{3} X_{3}+e \\
& Y=60,401+0,291 \cdot X_{1}+(-0,141) \cdot X_{2}+(-0,070) \cdot X_{3}+e
\end{aligned}
$$

\section{Uji Hipotesis dan Pembahasan}

\section{Pengaruh Daya Tarik Iklan Televisi terhadap Pembelian Impulsif}

Untuk menguji daya tarik iklan televisi $\left(\mathrm{X}_{1}\right)$ terhadap pembelian impulsif $(\mathrm{Y})$ penulis menggunakan SPSS 22,0 dengan hasil sebagaimana disajikan pada tabel berikut.

Tabel 2. Hasil Uji Regresi Linier Daya Tarik Iklan Televisi Terhadap Pembelian Impulsif

\section{Coefficients $^{\mathrm{a}}$}

\begin{tabular}{lrrrrrr}
\hline & \multicolumn{2}{c}{$\begin{array}{c}\text { Unstandardized } \\
\text { Coefficients }\end{array}$} & \multicolumn{2}{c}{$\begin{array}{c}\text { Standardized } \\
\text { Coefficients }\end{array}$} & & \\
\cline { 2 - 5 } Model & \multicolumn{2}{c}{ B } & Std. Error & Beta & t & \multicolumn{1}{c}{ Sig. } \\
\hline 1 (Constant) & 47,735 & 13,317 & & 3,585 &, 001 \\
& D_T_Iklan_Televisi &, 354 &, 168 &, 315 & 2,103 &, 042 \\
\hline
\end{tabular}

a. Dependent Variable: P_Impulsif

Dari tabel di atas, diketahui nilai Constant (a) sebesar 47,735, sedangkan nilai daya tarik iklan televisi (b/koefisien regresi) sebesar 0,315. Konstanta sebesar 47,735 mengandung arti bahwa nilai konsisten variabel pembelian impulsif adalah sebesar 47,735. Koefisien regresi $\mathrm{X}_{1}$ sebesar 0,315 menyatakan bahwa setiap penambahan $1 \%$ nilai daya tarik iklan televisi, maka nilai pembelian impulsif bertambah sebesar 0,315. Koefisien regresi tersebut bernilai positif sehingga dapat dikatakan bahwa arah pengaruh variabel $\mathrm{X}_{1}$ terhadap $\mathrm{Y}$ adalah positif.

Berdasarkan nilai signifikansi dari tabel di atas diperoleh nilai signifikansi sebesar $0,042<0,05$, sehingga dapat disimpulkan bahwa variabel daya tarik iklan televisi berpengaruh terhadap variabel pembelian impulsif $(\mathrm{Y})$. Berdasarkan nilai $\mathrm{t}$, diketahui nilai $t_{\text {hitung }}$ sebesar 3,585 $>t_{\text {tabel }}$ 1,684, sehingga dapat disimpulkan bahwa variabel daya tarik iklan televisi $\left(\mathrm{X}_{1}\right)$ berpengaruh terhadap variabel pembelian impulsif $(\mathrm{Y})$.

\section{Pengaruh Literasi Ekonomi terhadap Pembelian Impulsif}

Untuk menguji literasi ekonomi $\left(\mathrm{X}_{2}\right)$ terhadap pembelian impulsif (Y) penulis menggunakan SPSS 22,0 dengan hasil sebagaimana disajikan pada tabel berikut.

Tabel 3. Hasil Uji Regresi Linier Literasi Ekonomi Terhadap Pembelian Impulsif

\section{Coefficients ${ }^{\mathbf{a}}$}




\begin{tabular}{|c|c|c|c|c|c|c|}
\hline \multirow[b]{2}{*}{ Model } & & \multicolumn{2}{|c|}{ Unstandardized Coefficients } & \multirow{2}{*}{$\begin{array}{c}\text { Standardized } \\
\text { Coefficients } \\
\text { Beta }\end{array}$} & \multirow[b]{2}{*}{$\mathrm{t}$} & \multirow[b]{2}{*}{ Sig. } \\
\hline & & $\mathrm{B}$ & Std. Error & & & \\
\hline \multirow[t]{2}{*}{1} & (Constant) & 85,595 & 4,953 & & 17,281 &, 000 \\
\hline & L_Ekonomi &,- 274 & ,134 &,- 307 & $-2,042$ & ,048 \\
\hline
\end{tabular}

a. Dependent Variable: P_Impulsif

Dari tabel di atas, diketahui nilai Constant (a) sebesar 85,595, sedangkan nilai literasi ekonomi (b/koefisien regresi) sebesar -0,307. Konstanta sebesar 85,595 mengandung arti bahwa nilai konsisten variabel pembelian impulsif adalah sebesar 85,595. Koefisien regresi $\mathrm{X}_{2}$ sebesar $-0,307$ menyatakan bahwa setiap penambahan $1 \%$ nilai literasi ekonomi, maka nilai pembelian impulsif bertambah sebesar $-0,307$. Koefisien regresi tersebut bernilai negatif sehingga dapat dikatakan bahwa arah pengaruh variabel $\mathrm{X}_{2}$ terhadap $\mathrm{Y}$ adalah negatif.

Berdasarkan nilai signifikansi dari tabel di atas diperoleh nilai signifikansi sebesar $0,048<0,05$, sehingga dapat disimpulkan bahwa variabel literasi ekonomi televisi berpengaruh terhadap variabel pembelian impulsif (Y). Berdasarkan nilai $t$, diketahui nilai $t_{\text {hitung }}$ sebesar 17,281 $>t_{\text {tabel }} 1,684$, sehingga dapat disimpulkan bahwa variabel literasi ekonomi $\left(\mathrm{X}_{2}\right)$ berpengaruh terhadap variabel pembelian impulsif $(\mathrm{Y})$.

\section{Pengaruh Kontrol Diri terhadap Pembelian Impulsif}

Untuk menguji kontrol diri $\left(\mathrm{X}_{3}\right)$ terhadap pembelian impulsif $(\mathrm{Y})$ penulis menggunakan SPSS 22,0 dengan hasil sebagaimana disajikan pada tabel berikut.

Tabel 4. Hasil Uji Regresi Linier Kontrol Diri Terhadap Pembelian Impulsif Coefficients $^{\mathbf{a}}$

\begin{tabular}{|c|c|c|c|c|c|c|}
\hline \multirow{2}{*}{\multicolumn{2}{|c|}{ Model }} & \multicolumn{2}{|c|}{ Unstandardized Coefficients } & \multirow{2}{*}{$\begin{array}{c}\text { Standardized } \\
\text { Coefficients } \\
\text { Beta }\end{array}$} & \multirow[b]{2}{*}{$\mathrm{t}$} & \multirow[b]{2}{*}{ Sig. } \\
\hline & & $\mathrm{B}$ & Std. Error & & & \\
\hline \multirow[t]{2}{*}{1} & (Constant) & 84,378 & 4,305 & & 19,600 &, 000 \\
\hline & K Diri &,- 238 &, 115 &,- 312 & $-2,074$ & 045 \\
\hline
\end{tabular}

a. Dependent Variable: P_Impulsif

Dari tabel di atas, diketahui nilai Constant (a) sebesar 84,378, sedangkan nilai kontrol diri (b/koefisien regresi) sebesar -0,312. Konstanta sebesar 84,378 mengandung arti bahwa nilai konsisten variabel pembelian impulsif adalah sebesar 84,378. Koefisien regresi $X_{3}$ sebesar -0,312 menyatakan bahwa setiap penambahan $1 \%$ nilai kontrol diri, maka nilai pembelian impulsif bertambah sebesar -0,312. Koefisien regresi tersebut bernilai negatif sehingga dapat dikatakan bahwa arah pengaruh variabel $\mathrm{X}_{3}$ terhadap $\mathrm{Y}$ adalah negatif.

Berdasarkan nilai signifikansi dari tabel di atas diperoleh nilai signifikansi sebesar $0,045<0,05$, sehingga dapat disimpulkan bahwa variabel kontrol diri berpengaruh terhadap variabel pembelian impulsif (Y). Berdasarkan nilai t, diketahui nilai thitung sebesar 19,600 > $t_{\text {tabel }} 1,684$, sehingga dapat disimpulkan bahwa variabel kontrol diri $\left(\mathrm{X}_{3}\right)$ tidak berpengaruh terhadap variabel pembelian impulsif (Y).

\section{Pengaruh Daya Tarik Iklan Televisi, Literasi Ekonomi, dan Kontrol Diri secara bersama-sama terhadap Pembelian Impulsif}


Untuk menguji Pengaruh Daya Tarik Iklan Televisi, Literasi Ekonomi, dan Kontrol Diri $\left(\mathrm{X}_{1}, \mathrm{X}_{2}, \mathrm{X}_{3}\right)$ secara bersama-sama terhadap Pembelian Impulsif (Y) penulis menggunakan SPSS 22,0 dengan hasil sebagaimana disajikan pada tabel berikut.

Tabel 5. Hasil Uji F Secara Simultan

\begin{tabular}{|c|c|c|c|c|c|c|}
\hline \multicolumn{7}{|c|}{ ANOVA $^{a}$} \\
\hline \multicolumn{2}{|c|}{ Model } & $\begin{array}{l}\text { Sum of } \\
\text { Squares }\end{array}$ & df & Mean Square & $\mathrm{F}$ & Sig. \\
\hline \multirow[t]{3}{*}{1} & Regression & 270,343 & 3 & 90,114 & 2,472 &, $046^{\mathrm{b}}$ \\
\hline & Residual & 1384,990 & 38 & 36,447 & & \\
\hline & Total & 1655,333 & 41 & & & \\
\hline
\end{tabular}

a. Dependent Variable: P_Impulsif

b. Predictors: (Constant), L_Ekonomi, D_T_I_Televisi, K_Diri

Berdasarkan tabel di atas, nilai signifikansi pada tabel ANOVA dapat dilihat bahwa nilai signifikansinya adalah 0,046 $<0,05$ sehingga dapat diambil kesimpulan bahwa daya tarik iklan televisi, literasi ekonomi, dan kontrol diri secara bersama-sama berpengaruh terhadap pembelian impulsif.

Untuk melihat besarnya pengaruh daya tarik iklan televisi, literasi ekonomi, dan kontrol diri terhadap pembelian impulsif dapat dilihat dari nilai R Square yang terdapat pada tabel dibawah ini.

Tabel 6. Uji Estimate Daya Tarik Iklan Televisi, Literasi Ekonomi, Dan Kontrol Diri Terhadap Pembelian Impulsif

\begin{tabular}{|l|r|r|r|r|}
\hline Model & R & R Square & $\begin{array}{c}\text { Adjusted R } \\
\text { Square }\end{array}$ & $\begin{array}{c}\text { Std. Error of } \\
\text { the Estimate }\end{array}$ \\
\hline 1 &, $404^{\mathrm{a}}$ &, 163 &, 097 & 6,037 \\
\hline
\end{tabular}

Dari tabel di atas terlihat nilai $\mathrm{R}$ Square $=0,163$. Ini memberi arti bahwa Daya Tarik Iklan Televisi, Literasi Ekonomi, dan Kontrol Diri memberikan pengaruh terhadap pembelian impulsive yaitu sebesar 16,3\%, sedangkan sisanya $83,7 \%$ lagi dipengaruhi oleh variabel-variabel lain diluar penelitian ini.

\section{Pembahasan}

\section{Pengaruh Daya Tarik Iklan Televisi Terhadap Pembelian Impulsif}

Dari pengujian hipotesis yang dilakukan dapat disimpulkan bahwa terdapat pengaruh daya tarik iklan televisi terhadap perilaku pembelian impulsif pada Guru SMA Negeri Kabupaten Musi Banyuasin. Hasil ini sejalan dengan penelitian yang dilakukan oleh Yarahmadi (2011) yang menyimpulkan bahwa promosi penjualan berpengaruh signifikan terhadap pembelian impulsif. Promosi penjualan merupakan salah satu upaya perusahaan agar konsumen mencoba suatu barang atau jasa. Pemberian insentif seperti diskon waktu terbatas, akan memberikan nilai tambah dan merangsang konsumen untuk melakukan pembelian yang tidak direncanakan sebelumnya.

Ariani (2016) menyebutkan bahwa segala bentuk iklan memang difungsikan untuk menarik minat para konsumen. Televisi menggunakan iklan berbentuk video dengan durasi sekitar 3 menit. Beberapa penelitian sebelumnya menunjukkan bahwa iklan yang menarik 
dan berhasil mengikat emosi konsumen dapat meningkatkan pembelian impulsif. Iklan merupakan salah satu bentuk promosi yang paling dikenal dan paling banyak dibahas orang, hal ini kemungkinan karena daya jangkauannya yang luas. Iklan juga menjadi instrumen promosi yang sangat penting, khususnya bagi perusahaan yang memproduksi barang atau jasa yang ditunjukan kepada masyarakat luas (Morissan, 2010:18).

\section{Pengaruh Literasi Ekonomi Terhadap Pembelian Impulsif}

Dari pengujian hipotesis yang dilakukan dapat disimpulkan bahwa terdapat pengaruh literasi ekonomi terhadap perilaku pembelian impulsif pada Guru SMA Negeri Kabupaten Musi Banyuasin. Hal ini sejalan dengan hasil penelitian Pratiwi (2017) yang mengemukakan bahwa literasi ekonomi berpengaruh positif terhadap perilaku pembelian impulsif produk fashion.

Literasi ekonomi merupakan alat yang berguna untuk mengubah perilaku dari tidak cerdas menjadi cerdas. Seperti bagaimana memanfaatkan pendapatan untuk menabung, berinvestasi, proteksi dan memenuhi kebutuhan hidup. Literasi ekonomi juga berguna untuk membuka persepsi yang terbelenggu akibat kurangnya pengetahuan tentang biaya/manfaat (cost/benefit) (Peter Sina, 2012:135).

Menurut Jappelli dalam Nuraeni (2015:18) literasi ekonomi merupakan alat untuk mencapai tujuan, hanya saja pada kenyataannya tidak semua orang memiliki literasi ekonomi yang tinggi sehingga mengkerucutkan peluang mencapai kesejahteraan. Salah satu indikatornya adalah menjadi orang yang cerdas dalam mengelola sumber daya ekonominya guna mencapai kesejahteraan.

\section{Pengaruh Kontrol Diri Terhadap Pembelian Impulsif}

Dari pengujian hipotesis yang dilakukan dapat disimpulkan bahwa terdapat pengaruh kontrol diri terhadap perilaku pembelian impulsif pada Guru SMA Negeri Kabupaten Musi Banyuasin. Hasil ini sejalan dengan hasil penelitian Rozaini (2019) yang menyimpulkan bahwa kontrol diri berpengaruh negatif dan signifikan terhadap perilaku pembelian impulsif. Selain itu Pratiwi (2017) dalam penelitiannya juga menyimpulkan bahwa kontrol diri berpengaruh positif terhadap perilaku pembelian impulsif.

Kontrol diri merupakan kapasitas dalam diri (self) yang dapat digunakan untuk mengontrol variabel-variabel luar yang menentukan tingkah laku. Namun, variabel luar tersebut menentukan tingkah laku, tetapi ada peran kontrol pada dirinya. Hal ini karena tingkah laku disebabkan dan dipengaruhi oleh variabel eksternal, seberapapun kuatnya stimulus eksternal itu manusia masih dapat mengubahnya menggunakan proses kontrol diri (self control) (Hoyri, 2014:49).

Menurut Chaplin dalam Sarah (2014:316) mengatakan bahwa kontrol diri adalah kemampuan untuk membimbing tingkah laku sendiri, kemampuan untuk menekan atau merintangi dorongan atau tingkah laku impulsif. Selain itu, pengendalian tingkah laku mengandung makna yaitu melakukan pertimbangan-pertimbangan terlebih dahulu sebelum memutuskan sesuatu untuk bertindak. Adanya kontrol diri akan menjadikan individu lebih dapat memandu, mengarahkan dan mengatur pribadi dengan kuat yang akhirnya menuju pada sesuatu yang baik. Pola kerja pada kontrol diri tersebut yaitu dengan menolak pola respon yang terbentuk dan menggantinya dengan yang lain. Respon penggantinya sendiri terdiri dari penggunaan pemikiran, pengubahan emosi, pengaturan dorongan dan pengubahan tingkah laku. Kaitannya dengan keputusan pembelian, sebuah kontrol diri dikatakan berhasil ketika seseorang mampu memilih sesuatu secara tidak tergesa-gesa. 
Dengan kata lain, seseorang tersebut akan memikirkan pembelian secara teliti dan seksama. Sehingga kontrol diri cenderung mampu meminimalkan terjadinya perilaku pembelian yang tidak rasional.

\section{Pengaruh Daya Tarik Iklan Televisi, Literasi Ekonomi, dan Kontrol Diri secara bersama-sama terhadap Pembelian Impulsif}

Dari pengujian hipotesis yang dilakukan dapat disimpulkan bahwa daya tarik iklan televisi, literasi ekonomi, dan kontrol diri secara bersama-sama berpengaruh terhadap pembelian impulsif. Hal ini sesuai dengan hasil penelitian Fernanda (2019) dengan jurnalnya yang berjudul "Pengaruh Promosi Penjualan, Daya Tarik Iklan Internet, Dan Kualitas Website Terhadap Pembelian Impulsif" menunjukkan bahwa masing-masing variabel promosi penjualan, daya tarik iklan internet, dan kualitas website berpengaruh secara positif dan signifikan terhadap pembelian impulsif.

Selain itu Rozaini (2019) dengan judul "Pengaruh Literasi Ekonomi Dan Kontrol Diri Terhadap Perilaku Pembelian Impulsif Untuk Produk Fashion". Hasil uji t (parsial) menunjukkan literasi ekonomi tidak terdapat pengaruh negatif dan signifikan terhadap perilaku pembelian impulsif. Kontrol diri berpengaruh negatif dan signifikan terhadap perilaku pembelian impulsif. Secara simultan, kategori literasi ekonomi dan kontrol diri berpengaruh negatif dan signifikan terhadap perilaku pembelian impulsif.

Pembelian impulsif merupakan fenomena psikoekonomik yang banyak melanda kehidupan masyarakat. Pada proses membeli impulsif, calon pembeli langsung mengarah kepada suatu produk tertentu dan kemudian melakukan pembelian secara cepat. Perilaku pembelian impulsif timbul secara tidak sadar pada saat individu melakukan kegiatan yang berkaitan dengan uang dan gaya hidup. Sebagai contoh, ketika seseorang dengan teman sebayanya berjalan-jalan di pusat perbelanjaan atau mall yang tujuannya hanya sekedar jalanjalan atau mengisi waktu luang kemudian melihat produk dengan model terbaru atau melihat adanya potongan harga (discount) pada produk tertentu, akhirnya memutuskan membeli meskipun ketika berangkat tidak ada rencana untuk membeli.

Pembelian impulsif juga seringkali terjadi pada produk-produk yang dirasa cukup menarik bagi kelompok konsumen, salah satunya adalah produk fashion yang terdiri dari pakaian, celana, sepatu, sandal, jam tangan, kerudung, topi dan tas yang berfungsi sebagai sarana meningkatkan self image dan mood. Melalui produk fashion tersebut dapat terlihat lebih modis dan menawan. Fenomena tersebut terjadi karena konsumen saat ini cenderung memiliki kontrol diri yang rendah, termasuk dalam perilaku pembelian sehingga mereka berperilaku impulsif. Pada dasarnya, pembelian impulsif dapat ditekan dan bahkan dihindari apabila konsumen memiliki sistem pengendalian internal pada dirinya yang disebut dengan kontrol diri. Kontrol diri adalah perasaan bahwa seseorang dapat membuat keputusan dan mengambil tindakan yang efektif untuk menghasilkan suatu hal yang diinginkan dan menghindari suatu hal yang tidak diinginkan. Sesuai dengan yang diungkapkan Hoyri (2014: 52) bahwa kontrol diri merupakan kemampuan individu untuk menentukan perilakunya berdasarkan standar tertentu seperti moral, nilai, dan aturan di masyarakat agar mengarah pada perilaku positif. Terkait dengan perilaku konsumsi sebagai seorang guru, pendidikan memegang peranan penting dalam meningkatkan sumber daya manusia berkualitas. Dengan kata lain, orang dianggap belajar jika menunjukkan perubahan-perubahan tingkah laku dalam hidupnya, sehingga literasi ekonomi menjadi hal penting. 


\section{KESIMPULAN DAN SARAN}

Kesimpulan: 1) Terdapat pengaruh yang signifikan antara daya tarik iklan televisi terhadap pembelian impulsif dengan arah pengaruh positif. Ini mengandung arti bahwa daya tarik iklan televisi yang semakin baik akan meningkatkan pembelian impulsif guru.; 2) Terdapat pengaruh yang signifikan antara literasi ekonomi terhadap pembelian impulsif dengan arah pengaruh negatif. Ini mengandung arti bahwa rendahnya literasi ekonomi maka akan meningkatkan pembelian impulsif guru; 3) Terdapat pengaruh yang signifikan antara kontrol diri terhadap pembelian impulsif dengan arah pengaruh negatif. Ini mengandung arti bahwa rendahnya kontrol diri maka akan meningkatkan pembelian impulsif guru; dan 4) Terdapat pengaruh daya tarik iklan televisi, literasi ekonomi, dan kontrol diri secara bersamasama terhadap pembelian impulsif terhadap pembelian impulsif. Ini mengandung arti bahwa daya tarik iklan televisi, literasi ekonomi dan kontrol diri yang mempengaruhi terjadinya pembelian impulsif.

Saran: 1) Produsen harus banyak memiliki inovasi-inovasi baru dan selalu peka mengikuti perkembangan trend yang muncul di mansyarakat khususnya guru untuk memancing impulsivitas konsumen terhadap produknya. Iklan-iklan dibuat semenarik mungkin dan bersifat sugestibel serta mudah dilihat sehingga lebih dapat menimbulkan ketertarikan yang mendorong guru melakukan impulsive buying pada produk tersebut. Untuk memasarkan produk juga bisa dilakukan melalui internet yaitu marketplace, online shop di sosial media seperti facebook, instagram dan masih banyak lagi; 2) Diharapkan bagi konsumen khususnya guru yang telah memiliki literasi ekonomi yang baik dapat mengaplikasikan ilmu-ilmu ekonomi secara efektif agar terhindar dari perilaku pembelian impulsif atau pembelian yang tidak terencana (terduga). Selain literasi ekonomi, guru juga diharapkan lebih selektif dalam melakukan pembelian suatu produk agar sesuai dengan kemampuan ekonomi yang dimiliki. Hasil dalam penelitian ini juga menunjukkan bahwa terdapat peran negatif kontrol diri terhadap pembelian impulsif pada guru. Saran yang dapat diberikan dari penelitian ini kepada guru adalah untuk meningkatkan kontrol diri agar dapat menghindari pembelian impulsif; dan 3) Hendak meneliti maupun mengembangkan penelitian serupa, peneliti menyarankan agar mempertimbangkan variasi dari sampel yang akan diteliti dan tentunya dengan variabel lain yang tidak diteliti dalam penelitian ini. Penelitian selanjutnya dapat memilih spesifikasi produk-produk lain yang mungkin merupakan objek impulsive buying yang lebih besar dari produk-produk fashion. Dan perlu dilakukan penelitian terhadap subjek lain misalnya ibu-ibu rumah tangga yang memiliki peran besar dalam pengaturan ekonomi rumah tangga.

\section{DAFTAR RUJUKAN}

Abbas, N., \& Awan, A.G. (2015). Impact Of Demographic Factors On Impulse Buying Behavior Of Consumers Ini Multan-Pakistan. European Journal of Business and Management. 7 (22).

Ariani, Nur., Rizka, Maulidya. (2016). Pengaruh Daya Tarik Iklan Online Shop terhadap Pembelian Impulsif (Impulsive Buying) pada Mahasiswi Fakultas Psikologi Universitas Islam Negeri (UIN) Maulana Malik Ibrahim. Malang : Universitas Islam Negri Maulana Malik Ibrahim.

Bong, S. (2011). Pengaruh In-Store Stimuli Terhadap Impulse Buying Behavior Konsumen Hypermarket di Jakarta. Ultima Manajemen, Vol. 3 No. 1.

Budiwati, Neti. (2014). Analisis Literasi Ekonomi dan Perilaku Konsumen. Disertasi. Bandung: Universitas Pendidikan Indonesia. 
Dendy, Triadi Bharata., \& Addy, Sukma. (2010). Ayo Bikin Iklan: Memahami Teori dan Praktek Iklan Media Lini Bawah. Jakarta: PT. Elex Media Komputindi.

Fernanda, Maria. (2019). Pengaruh Promosi Penjualan, Daya Tarik Iklan Internet, Dan Kualitas Website Terhadap Pembelian Impulsif. Jurnal Manajemen Bisnis Dan Kewirausahaan/Vol. 3/No.5/September - 2019:07-12.

Ghufron, M. N. \& Rini R. S. (2014). Teori-Teori Psikologi. Yogyakarta: Ar-Ruzz Media.

Hoyri S, Imam. (2014). Kontrol Diri Dan Perilaku Konsumtif Pada Siswa SMA (Ditinjau Dari Lokasi Sekolah). Jurnal Online Psikologi. Vol. 2 No.1.

Kharis, Ismu Fadli. (2011). Studi Mengenai Impulse Buying dalam Penjualan Online (Studi Kasus di Lingkungan Universitas Diponegoro Semarang). Jurnal Universitas Diponegoro Semarang.

Liliweri, Alo. (2011). Komunikasi : Serba Ada Serba Makna. Jakarta : Kencana.

Marhayati. (2012). Hubungan Antara Loneliness Terhadap Impulsive Buying Produk Fashion Pada Mahasiswi Konsumen Online Shop. Skripsi Fakultas Psikologi Universitas Islam Negeri Maulana Malik Ibrahim Malang.

Morissan, A.M. (2010). Periklanan Komunikasi Pemasaran Terpadu. Jakarta: Penerbit Kencana.

Neilsen, 2017. Cross Platform Report. Diakses pada tanggal 11 Januari 2020. http://www.nielsen.com/id/en/press-room/2017/THE-NEWTRENDSAMONGSTINDONESIAN-NETIZEN

Nuraeni. (2015). Pengaruh Literasi Ekonomi, Kelompok Teman Sebaya, Dan Kontrol Diri Terhadap Perilaku Pembelian Impulsif Untuk Produk Fashion Pada Mahasiswa Fakultas Ekonomi Universitas Negeri Yogyakarta. Yogyakarta : UNY

Paramita, Adiska O., Zainul Arifin, dan Sunarti. (2014). Pengaruh Nilai Belanja Hedonis Terhadap Pembelian Impulsif Pada Toko Online Dengan Emosi Positif Sebagai Variabel Perantara. Jurnal Administrasi Vol.8 No.2.

Pratiwi, Indah. (2017). Pengaruh Literasi Ekonomi, Kelompok Teman Sebaya Dan Kontrol Diri Terhadap Perilaku Pembelian Impulsif Untuk Produk Fashion Di Online Shop Pada Mahasiswa Jurusan Pendidikan Ekonomi Undiksh. Jurnal Pendidikan Ekonomi Undiksha. Vol. 9 No.1.

Rahman, David J. (2012). Pengantar Ilmu Administrasi Niaga. Jakarta: Karunia.

Rozaini, Noni. (2019). Pengaruh Literasi Ekonomi Dan Kontrol Diri Terhadap Perilaku Pembelian Impulsif Untuk Produk Fashion. Niagawan, Vol. 8 No. 1.

Sarah, Dira. (2014). Peranan Kontrol Diri Terhadap Pembelian Impulsif Pada Remaja Berdasarkan Perbedaan Jenis Kelamin Di Samarinda. Ejournal Psikologi, 1 (3).

Sina, Peter, G. (2012). Analisis Literasi Ekonomi. Jurnal Economia. Vol.8 No.2.

Sugiyono. (2017). Metode Penelitian Kuantitatif, Kualitatif dan $R \& D$. Bandung: Alfabeta.

Syamsul, B.T. (2010). Psikologi Pendidikan Berbasis Analisis Empiris Aplikatif. Jakarta: Kencana.

Utami, Christina Whidya. (2010). Manajemen Ritel : Strategi dan Implementasi Operasional Bisnis Ritel Modern di Indonesia (edisi 2). Jakarta: Salemba Empat.

Yarahmadi, Hasti dan Karbasivar Alireza. (2011). Evaluating Effective Factors on Consumer Impulse Buying Behavior. Asian Journal of Business Management Studies, 2 (4), 174181. 